\title{
Glutathione-S-transferase production in earthworm (Annelida: Eudrilidae) as a tool for heavy metal pollution assessment in abattoir soil
}

\author{
Owagboriaye Folarin $\mathrm{Ojo}^{1 *}$, Dedeke Gabriel Adewumi ${ }^{2} \&$ Ademolu Kehinde Oluwatoyin ${ }^{2}$ \\ 1. Department of Plant Science and Applied Zoology, Faculty of Science, Olabisi Onabanjo University, Ago-Iwoye, \\ Ogun State, Nigeria; fobillion@yahoo.com • * Correspondence. \\ 2. Department of Biological Sciences, College of Natural Sciences, Federal University of Agriculture, Abeokuta, \\ Nigeria: gabrieldedekson@gmail.com, ademoluko@unaab.edu.ng
}

Received 16-III-2015. C Corrected 25-I-2016. Accepted 25-II-2016.

\begin{abstract}
The use of direct response of animals to environmental challenges by production of biomarkers is a better tool to assess environmental pollution than the conventional methods. This study aimed to measure Glutathione-S-transferase (GST) in earthworms as tools for assessing heavy metal pollution in abattoir soil. Five (5) replicates each of earthworm species (Libyodrilus violaceous, Eudrilus engeniae and Alma millsoni), soil and rumen waste samples were collected from three (3) abattoir sites (Lafenwa, Gbonogun and Madojutimi abattoirs), and a control site located within Federal University of Agriculture Abeokuta, beside an undisturbed stream with no rumen waste. Heavy metal $(\mathrm{Cu}, \mathrm{Zn}, \mathrm{Pb}, \mathrm{Cd}, \mathrm{Co}, \mathrm{Cr}, \mathrm{Ni}$ and $\mathrm{Mn})$ concentrations in rumen waste, abattoir soils and earthworm tissues were determined using Atomic Absorption Spectrophotometer. The $\mathrm{pH}$ and organic matter $(\mathrm{OM})$ concentrations of the rumen waste and abattoir soils were determined by standard methods. GST activities in the earthworm tissues were determined through the conjugation of $1 \mathrm{mM}$ reduced glutathione (GSH) with $1 \mathrm{mM}$ 1-chloro-2,4-dinitrobenzene (CDNB). The rumen waste recorded significantly higher ( $\mathrm{p} \leq$ $0.05) \% \mathrm{OM}$, heavy metal concentrations and $\mathrm{pH}$ level than in their respective abattoir soils. The mean heavy metal concentrations of $\mathrm{Cu}, \mathrm{Zn}, \mathrm{Pb}, \mathrm{Cd}$ and $\mathrm{Mn}$ were highest in the tissue of earthworm species obtained from Lafenwa abattoir. A significantly $(\mathrm{p} \leq 0.05)$ higher GST activities were recorded in the tissue of earthworm species obtained from Lafenwa and Gbonogun abattoirs. Libyodrilous violaceus obtained from Lafenwa abattoir recorded the highest GST activity $(8.47 \pm 1.39)$ in their tissue followed by the ones from Gbonogun abattoir $(8.21 \pm 0.85)$. A significant $(\mathrm{p} \leq 0.05)$ positive correlations was observed between GST activities in earthworm tissues and heavy metal concentrations. GST activities can therefore be used to assess the level of heavy metal pollution in abattoir soils. Rev. Biol. Trop. 64 (2): 779-789. Epub 2016 June 01.
\end{abstract}

Key words: biomarker, waste, human activities, meat processing, oligochaeta.

Pollution is currently a global problem that exists in various dimensions and it becomes worse when the level of pollution cannot be determined in an environment (Asonye, Okolie, Okenwa, \& Iwuanyanu, 2007).

Human activities has been regarded as one of the major source and contributor of impurities in the form of industrial, domestic, agricultural and chemical wastes to the environment (Merrington, Winder, Parkinson, \& Redman, 1984). In many parts of the world, human activities negatively impact the environment and biodiversity. Some of the consequences of man-made pollution include transmission of diseases by water borne pathogens, eutrophication of natural water bodies, accumulation of toxic or recalcitrant chemicals in the soil, destabilization of ecological balance and negative effects on human health (Walker, 1998).

The past few decades have witnessed an enormous increase in soil pollution due to the intensive use of biocides and fertilizers in agriculture, industrial activities, urban waste and atmospheric deposition (Criel et al., 2008). 
Its occurrence is related to the degree of industrialization and intensity of chemical use. Soil pollution causes decrease in soil fertility, alteration of soil structure, disturbance of the balance between flora and fauna residing in the soil, contamination of the crops, and contamination of groundwater, constituting a threat for living organisms (Bezchlebova, Cernohlavkova, Ivan Sochova, Kobeticova, \& Hofman, 2007). The most diffusive chemicals occurring in soil are heavy metals, pesticides and petroleum (Lanno, Wells, Conder, Bradham, \& Basta, 2004).

The sources of heavy metal pollution include natural sources (Miranda et al., 2009), like mining or metal smelting (Haimi \& Mätäsniemi, 2002), animal manure on agricultural land (Salehi \& Tabari, 2008), and aerial deposition of particulates from vehicular emission (Ward \& Savage, 1994).

High protein demand in the country has significantly increased meat production, resulting in the release of solid, liquid and gaseous wastes from meat processing facilities to the environment. Solid and liquid wastes tend to be worrisome due to the high content of putresible organic matter, which can lead to the depletion of oxygen and an impairment or disruption of water and soil eco-functionality and a preponderance of disease-causing organisms.

Meat processing wastes come from stockyards, abattoirs and packing plants. All these contain blood, fats, protein, gut contents, heavy metals, antibodies, hormones and other substances (Itodo \& Awulu, 1991). In many developing nations such as Nigeria, many abattoirs dispose off their waste directly into streams or rivers and also use water from the same source to wash slaughtered meat (Adelegan, 2002).

Due to the increasing concern about chemical contamination of soil from abattoir, there is an increasing interest of the scientific community and international agencies for soil pollution monitoring and assessment. Hence, new biological approaches to soil monitoring and assessments, such as the measurement of biochemical and cellular responses to pollutants (i.e. biomarkers) on organisms living in the soil (bioindicators), have become of major importance for the assessment of the quality of this environmental compartment (Rao, Pavan, $\&$ Madhavendra, 2003). Soil invertebrates may serve as good sentinel organisms of soil pollution because they are in direct contact with soil, in contrast to many vertebrates, that are indirectly exposed through the food chain (Rao et al., 2003).

Contamination by heavy metals, particularly lead and zinc, has been detected in many abattoir areas (Coker, Olugasa, \& Adeyemi, 2001).

Among terrestrial invertebrates, earthworms are priority test organisms for soil contamination surveys because they are easy to handle, widespread in their terrestrial distribution and have the capacity to accumulate and concentrate large quantities of inorganic and organic pollutants (Rao et al., 2003); besides, they may acquire adaptive resistance to the toxicity of these pollutants including heavy metals (Corp \& Morgan, 1991). Earthworms are frequently exposed to heavy metals, pesticides, microbes and other pollutants in the environment, and are therefore dependent on efficient detoxification systems for their survival.

Few studies on oxidative stress and antioxidant defenses in earthworms have been carried out. Booth, Heppelthwaite and Mc Glinchy (2000) reported the existence of the glutathione (GSH) and glutathione-S-transferase (GST) system in earthworms. Saint-Denis, Narbonne, Arnaud, and Ribera (2001) studied the activities of enzymes (catalase, glutathione peroxidase, glutathione-S-transferase and glutathione reductase) involved in antioxidant defence systems in Eisenia fetida, which are mainly localized in the cytosolic fractions. In response to organic and inorganic pollutant perturbations of glutathione concentration, the activity of glutathione-S-transferases, glutathione reductase and glutathione peroxidase have been previously reported in earthworm (Qaszczyca et al., 2004). Hence, earthworms have been shown to be valuable indicators of soil pollution (Lanno et al., 2004). This study therefore aimed at evaluating Glutathione-s-transferase production in indigenous earthworm, as tool 
for heavy metal pollution assessment in abattoir soil.

\section{MATERIALS AND METHORDS}

Study location: This work was carried out in Abeokuta, Ogun State, South-Western Nigeria $\left(7^{\circ} 02^{\prime} \mathrm{N}-3^{\circ} 35^{\prime} 42^{\prime \prime} \mathrm{E}\right)$. It borders Lagos State to the South, Oyo and Osun states to the North, Ondo State to the East and the Republic of Benin to the West. The total area of the state is $16762 \mathrm{~km}^{2}$.

Study sites: Earthworm and soil samples were collected from three different abbatoir sites and a control site within two local goverments in Abeokuta metropolis in Ogun state. The sampling sites were: Lafenwa OdoEran abbatoir $\left(07^{\circ} 163^{\prime} \mathrm{N}-003^{\circ} 328^{\prime} 27^{\prime \prime} \mathrm{E}\right)$, Gbonogun abbatoir $\left(07^{\circ} 179^{\prime} \mathrm{N}-003^{\circ} 406^{\prime} 25^{\prime \prime}\right.$ E), Odo-Eran Asejere Madojutimi abbatoir $\left(07^{\circ} 163^{\prime} \mathrm{N}-003^{\circ} 376^{\prime} \mathrm{E}\right)$, and the control site, Federal University of Agriculture Abeokuta Arboretum $\left(07^{\circ} 224^{\prime} \mathrm{N}-003^{\circ} 450^{\prime} \mathrm{E}\right)$. The general description of the abattoir sites is shown in Table 1.

Sample collection: Earthworm and soil samples were collected from all three abattoir sites and the control site, by the digging and hand sorting method according to the standard method of Owa (1992). Distance measure was taking into consideration during sampling, i.e samples were collected $1 \mathrm{~m}$ intervals on the sites. Soil and earthworm samples were collected in five replicates at each sampling site.

Analysis of the soil pH: Soil and rumen waste samples were collected, and their $\mathrm{pH}$ were measured according to the method of Davey and Conyers (1988). For this, $20 \mathrm{~g}$ of air dried samples were weighed and mixed with $20 \mathrm{~mL}$ of distilled water in a $50 \mathrm{~mL}$ beaker. The mixtures were allowed to stand for 30 minutes with occasional stirring with a glassrod. The electrodes of the calibrated $\mathrm{pH}$ meter were then inserted into the partly settled suspension, and the $\mathrm{pHs}$ of the samples were measured.

Determination of the percentage organic matter: The soil and rumen waste organic matter percentage was determined by the method described by Nelson and Bomers (1982). Samples were ground using a $0.5 \mathrm{~mm}$ sieve, weighed in duplicate and transferred to a 250 $\mathrm{mL}$ erlenmeyer flask. Each sample was added with a volume of $10 \mathrm{~mL}$ of $1 \mathrm{M}$ potassium dichromate (and swirled gently to disperse the sample), and by the addition of $20 \mathrm{~mL}$ of concentrated sulphuric acid; the mixture was swirled gently until samples and reagents were throughly mixed. The mixtures were then allowed to stand for 30 minutes on a glass plate. Finally, each mixture was added with $100 \mathrm{~mL}$ of distilled water, followed by the addition of 3-4 drops of ferroin indicator, after which it was titrated with $0.5 \mathrm{~N}$ ferrous

TABLE 1

General description of the three abattoir sites

\begin{tabular}{llll}
\multicolumn{1}{c}{ Characteristics } & \multicolumn{1}{c}{ Lafenwa Abattoir } & \multicolumn{1}{c}{ Gbonogun Abattoir } & \multicolumn{1}{c}{ Madojutimi Abattoir } \\
Age (Years) & 60 & 25 & 08 \\
Size & 400 square meters & 350 square meters & 320 square meters \\
Building Status/construction & $\begin{array}{l}\text { Empty concrete buildings with } \\
\text { very wide open space. The } \\
\text { buildings lack basic facilities. }\end{array}$ & $\begin{array}{l}\text { Empty concrete buildings with } \\
\text { very wide open space. The } \\
\text { buildings lack basic facilities. }\end{array}$ & $\begin{array}{l}\text { Very strong concrete buildings } \\
\text { with wide open space. The } \\
\text { buildings lack basic facilities. }\end{array}$ \\
Soil & $\begin{array}{l}\text { Moist and loamy. } \\
\text { Cattle }\end{array}$ & $\begin{array}{l}\text { Moist and loose loamy } \\
\text { Animal slaughter }\end{array}$ & $\begin{array}{l}\text { Cattle } \\
\text { Frequency and number of } \\
\text { animal slaughter }\end{array}$ \\
\hline
\end{tabular}


sulphate solution. A titration blank was similarly prepared.

The percentage organic carbon was given by the equation:

$$
\frac{\left(\mathrm{Mek}_{2} \mathrm{Cr}_{2} \mathrm{O}_{7}-\mathrm{MeFeSO}_{4}\right) \times 0.0031 \times 100 \times \mathrm{F}}{\text { Mass (g) of air dried samples }}
$$

$\mathrm{F}=$ Correctionfactor $(1.33)$

$\mathrm{Me}=$ Normality of solution $\mathrm{x} \mathrm{mL}$ of solution used

$\%$ organic matter in samples $=\%$ organic carbon $\times 1.729$.

Heavy metal analysis: This involves sample digestion and the determination of the heavy metal concentration in the digested samples according to the method of the Association of Analytical Chemists, AOAC (2000).

Sample digestion was made by wet oxidation. To $0.2 \mathrm{~g}$ of earthworm and rumen waste samples, $5 \mathrm{~g}$ of soil sample, $2 \mathrm{~mL}$ sulphuric acid, $4 \mathrm{~mL}$ perchloric acid and $20 \mathrm{~mL}$ nitric acid were added, and the mixture was heated to boil on heating mantle until the mixture turned colourless. The mixture was allowed to cool and then was diluted with distilled water for a final volume of $100 \mathrm{~mL}$.

Following sample digestion, an atomic absortion spectrophotometer was used to determine the concentration of the following heavy metals in the digest of earthworm tissue, rumen waste and soil sample: Lead $(\mathrm{Pb})$, Zinc (Zn), Cupper $(\mathrm{Cu})$, Chromium (Cr), Cadmium (Cd), Cobalt (Co) and Nickel (Ni).

Determination of glutathione-S-transferase (GST): GST activity was determined following the procedure of Habig, Pabst, and Jakoby (1974) through the conjugation of 0.05 $\mathrm{mL}$ reduced glutathione (GSH) with $0.05 \mathrm{~mL}$ 1-chloro-2,4-dinitrobenzene (CDNB).

A $5 \%$ homogenate of earthworm tissue (whole body) was prepared in $20 \mathrm{mM}$ potassium phosphate buffer, pH 7.4 (0.1 M Nacl + $0.25 \mathrm{M}$ sucrose).

The formation of the adduct of DNB, S-2,4-dinitrophenyl glutathione (DNPG) was monitored by measuring the rate of increase in absorbance at $340 \mathrm{~nm}$ in a spectrophotometer.

The enzyme activity was calculated from the extinction coefficient (GSH-CDNB) and expressed as nmol DNPG produced $\mathrm{min} / \mathrm{mg}$ protein.

\section{Calculations:}

$$
\text { Units } / \mathrm{mL} \text { enzyme }=\frac{(\Delta \mathrm{A} 340 \mathrm{~nm} / \mathrm{min} \text { Test }-\Delta \mathrm{A} 340 \mathrm{~nm} / \mathrm{min} \text { Blank }) \times \mathrm{V}(\mathrm{mL}) \times \mathrm{df}}{\varepsilon_{\mathrm{mM}} \times \mathrm{V}_{\mathrm{enz}}(\mathrm{mL})}
$$

Where:

$\mathrm{df}=$ the dilution factor of the original sample

$\varepsilon_{\mathrm{mM}}=$ the extinction coefficient for CDNB conjugate at $340 \mathrm{~nm}=9.6$

$\mathrm{V}=$ the reaction volume $=1.15 \mathrm{~mL}$

$\mathrm{V}_{\mathrm{enz}}=$ the volume of the enzyme sample tested $=0.05$

All the data were presented as the mean \pm standard deviation (SD). Statistical analyses for all measurements were performed by Statistical Package for Social Sciences (SPSS) version 16.0. The mean, standard deviation, Analysis of Variance (ANOVA) and Correlation coefficient were conducted. Post Hoc test was also conducted using Duncan Multiple Range Test (DMRT). $\mathrm{P}<0.05$ was considered to be statistically significant.

\section{RESULTS}

Eudrilus eugeniae and Libyodrilus violaceus were identified from both Lafenwa and Gbonogun abattoir while Alma millsoni and Libyodrilus violaceus were identified from Madojutimi abattoir. Alma millsoni was identified from the control site.

The $\mathrm{pH}$ was lowest in soil samples (Fig. 1A) of all abattoir locations than their respective rumen waste (Fig. 1B). The highest level of percentage organic matter was recorded in the soil of Lafenwa abattoir $(4.57 \pm 0.06)$, while the soil of the control site was lowest in percentage organic matter $(2.11 \pm 0.05)$. The level of percentage organic matter was highest in the 

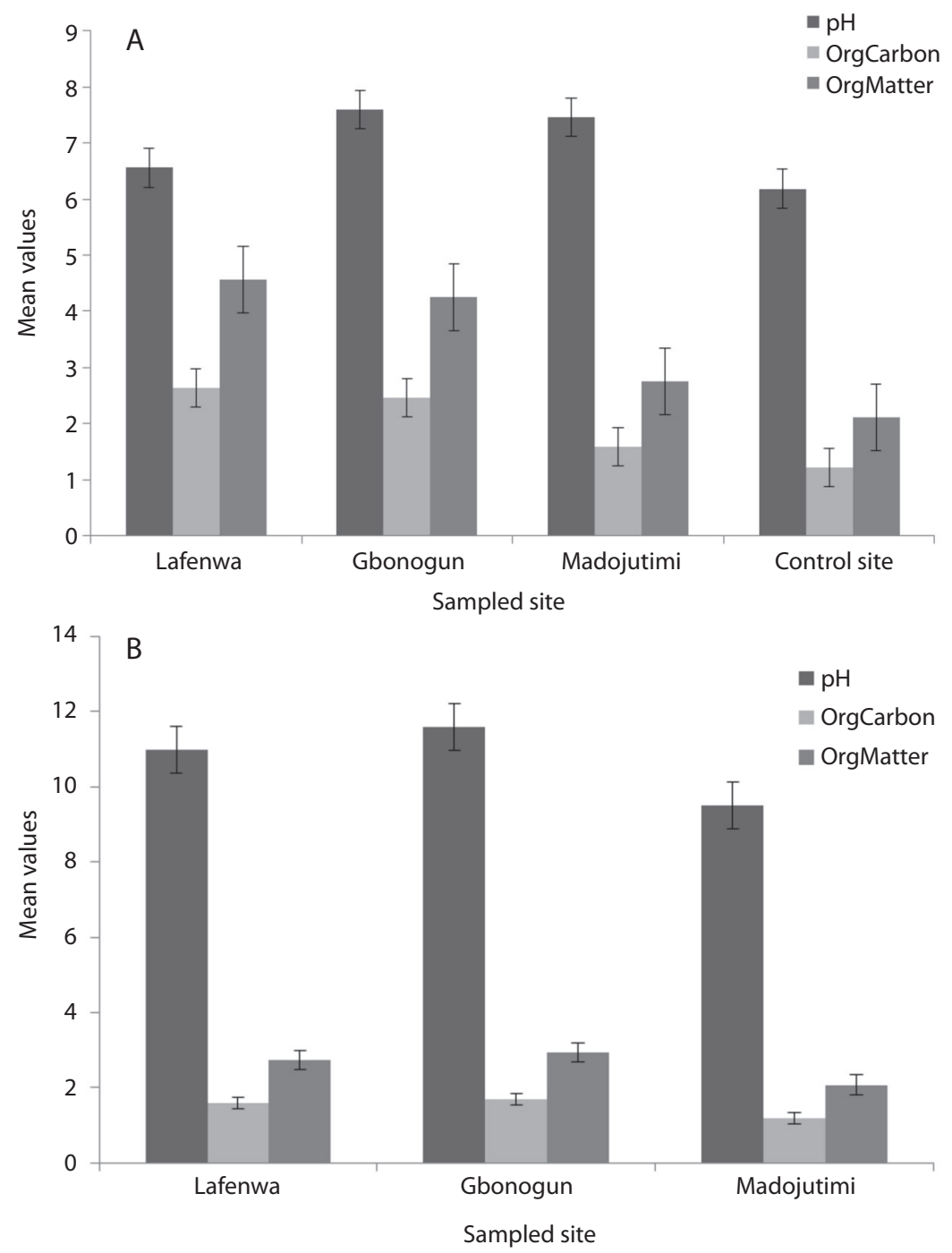

Fig. 1. A. $\mathrm{pH}$ and organic contents of the soils of Lafenwa, Gbonogun, Madojutimi abattoir and control site. B. $\mathrm{pH}$ and organic contents of the rumen wastes from Lafenwa, Gbonogun and Madojutimi abattoir.

rumen waste obtained from Gbonogun abattoir $(2.94 \pm 0.01)$ followed by rumen waste from Lafenwa abattoir $(2.73 \pm 0.01)$ and Madojutimi abattoir $(2.07 \pm 0.01)$, respectively. There was no significant difference $(\mathrm{P}>0.05)$ in the value of percentage organic matter from the soil of Gbonogun and Lafenwa abattoir.

The heavy metals concentrations recorded in the rumen waste of all the abattoir locations were significantly higher $(\mathrm{P}<0.05)$ than the metal concentrations in their respective soil samples. The soil samples obtained from the control site was significantly lower $(\mathrm{P}<0.05)$ in metal concentrations than the soil and rumen waste samples from the abattoir (Table 2). Values recorded for $\mathrm{Cu}, \mathrm{Pb}, \mathrm{Cd}$ and $\mathrm{Co}$ in the soil and rumen waste samples from all the abattoir locations were significantly different $(\mathrm{P}<$ $0.05)$. Lafenwa abattoir recorded the highest concentrations of $\mathrm{Zn}(28.06 \pm 0.30), \mathrm{Pb}(30.71$ $\pm 0.35), \mathrm{Cd}(10.78 \pm 0.19)$ and $\mathrm{Ni}(25.81 \pm$ 0.18 ) in its soil and rumen waste and Gbonogun 


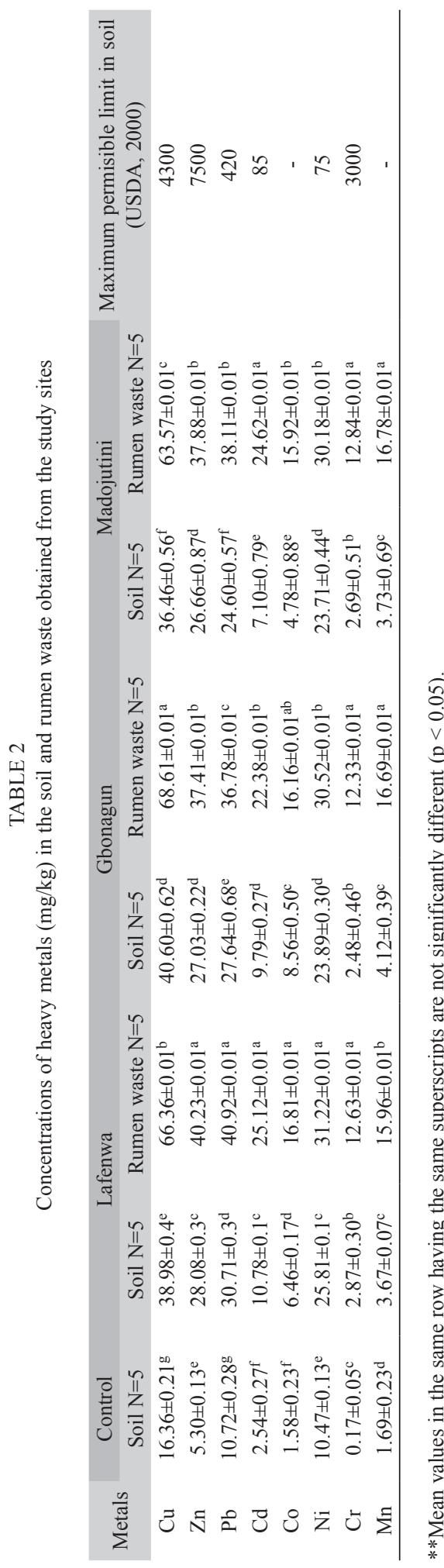

abattoir recorded the highest concentrations of $\mathrm{Cu}(40.60 \pm 0.62)$, Co $(8.56 \pm 0.50)$ and $\mathrm{Mn}(4.12 \pm 0.39)$ in its soil, while the lowest concentrations of all the heavy metals were recorded for the soil from the control site.

The heavy metals concentration in the tissue of all earthworm species obtained from the abattoir locations were significantly lower $(\mathrm{P}<0.05)$ than their respective abattoir soil. Libyodrilous violaceus has higher concentrations of all the heavy metals than other earthworm species from all the abattoir locations (Table 3). Mean heavy metal concentrations of $\mathrm{Cu}, \mathrm{Zn}, \mathrm{Pb}, \mathrm{Cd}$ and $\mathrm{Mn}$ was highest in the tissue of earthworms from Lafenwa abattoir, followed by earthworms from Gbonogun, then Madojutimi abattoir, while the earthworm species obtained from the control site recorded the lowest mean heavy metal concentrations in their tissues. There were no significant differences $(\mathrm{P}>0.05)$ between the values recorded for $\mathrm{Mn}, \mathrm{Cr}, \mathrm{Co}$ and $\mathrm{Zn}$ in the earthworm tissues obtained from all the abattoir locations, but these were significantly higher $(\mathrm{P}<0.05)$ than the values obtained for the earthworm tissue from the control site.

Concentration of GST was significantly higher $(\mathrm{P}<0.05)$ in the earthworm tissue obtained from all the abattoir sites, but the values obtained for the earthworm species from the control site was significantly lower $(\mathrm{P}<0.05)$ (Fig. 2). Highest GST concentration was recorded for Libyodrilous violaceus obtained from Lafenwa abattoir $(8.47 \pm 1.39)$ followed by Gbonogun abattoir $(8.21 \pm 0.85)$, while Alma milsoni collected from the control site recorded the lowest GST concentration in their tissue (1.30 \pm 0.25$)$ (Fig. 2). There were significant positive correlations between GST activities and the metal concentrations in all the earthworm species obtained from the study sites (Table 4).

\section{DISCUSSION}

We observed the use of earthworm's biomarker as a suitable tool for abattoir soil pollution assessment. The earthworm species 


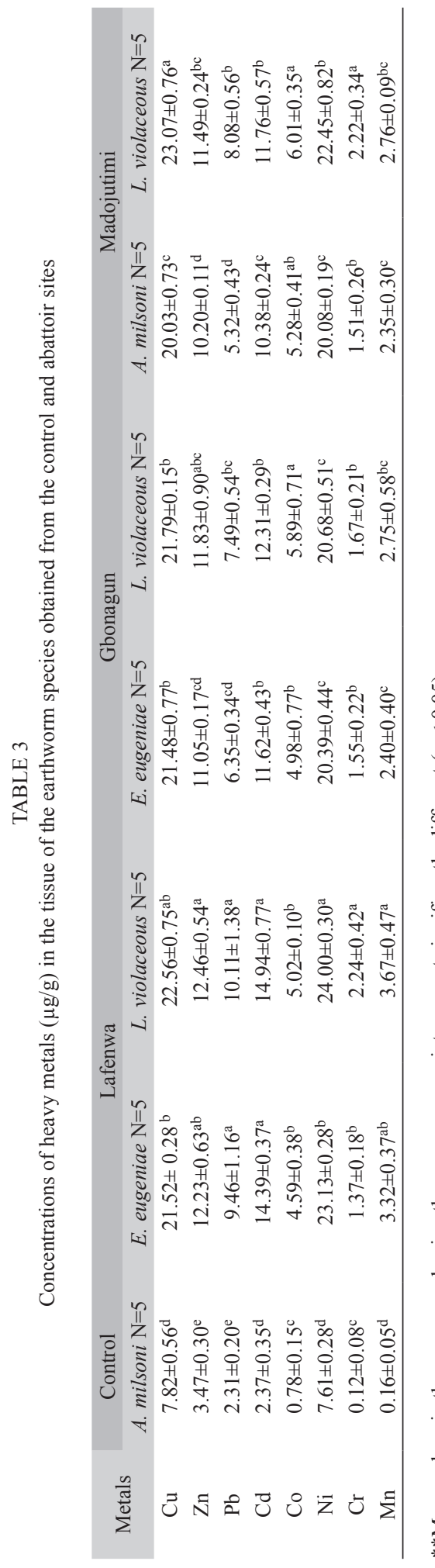

TABLE 4

Pearson correlation coefficient between GST activities and metal concentrations in earthworm

\begin{tabular}{ccc} 
& \multicolumn{2}{c}{ GST } \\
$\mathrm{Cu}$ & 0.887 & $\mathrm{p}$ value \\
$\mathrm{Zn}$ & 0.925 & $0.000^{* *}$ \\
$\mathrm{~Pb}$ & 0.802 & $0.000^{* *}$ \\
$\mathrm{Cd}$ & 0.931 & $0.000^{* *}$ \\
$\mathrm{Co}$ & 0.832 & $0.000^{* *}$ \\
$\mathrm{Ni}$ & 0.910 & $0.000^{* *}$ \\
$\mathrm{Cr}$ & 0.722 & $0.000^{* *}$ \\
$\mathrm{Mn}$ & 0.875 & $0.000^{* *}$ \\
\hline
\end{tabular}

**Correlation is significant at 0.01 level.

*Correlation is significant at 0.05 level.

variation identified in the sample site, could be attributed to the varying soil structure and composition inhabited by the earthworms as suggested by Svendsen, Spurgeon, Hankard, and Weeks (2004). This finding is comparable to the work of Hobbelen, Koolhaas and Van Gastel (2006) who also identified different earthworms species (Lumbricus rubellus and Apporectodea caliginosa) from an industrial field soil.

The old age and slaughtering activities at Gbonogun and Lafenwa abattoir sites could account for the observed higher level of organic matter and $\mathrm{pH}$ in their soil samples. The abattoir workers disposed undigested plant materials (rumen waste) in the rumen of the slaughtered cow on the abattoir soil and its environ which over the years served as a sinking ground for rumen waste, and consequently increased the soil organic matter and pH (Agbaire \& Emoyan, 2012).

The higher soil and rumen heavy metals concentrations recorded in the waste samples from Lafenwa abattoir could be attributed to the age of this abattoir and its high organic matter content. The soil organic matter acts as a "storehouse or reservoir" for many of these metals (Agbaire \& Emoyan, 2012); it therefore influences micronutrient availability through chelation. Positive correlation between some micronutrients availability and organic 


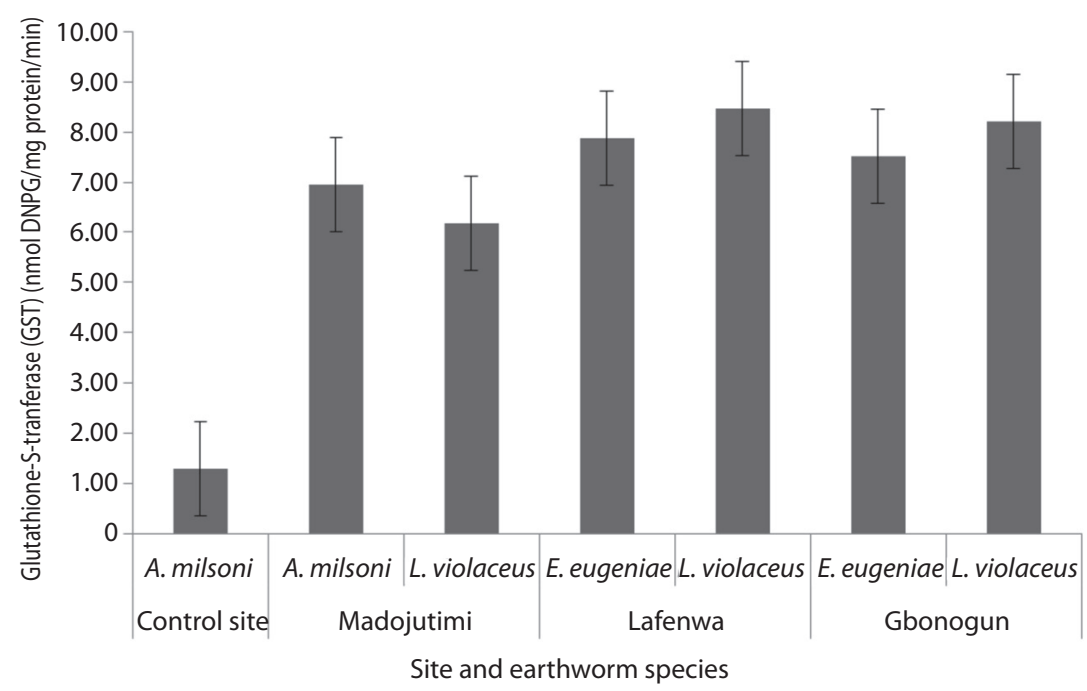

Fig. 2. Glutathione-S-tranferase (GST) (nmol DNPG/mg protein/min) concentration in the tissues of the earthworm species obtained from the abattoirs and control site.

matter had been reported (Sharma, Sharma, \& Megh, 2003). Lafenwa abattoir is the largest and oldest abattoir, with high rate of activities such as animal butchering and meat selling; it is followed by Gbonogun abattoir. Their ages and high activities could also account for the high metal and organic matter concentrations observed in the soil and rumen wastes. The significant increase in heavy metal concentrations recorded in the rumen waste obtained from all the abattoir sites may be attributable to the type and the feeding patterns of the cattle slaughtered at the abattoirs. These cattle, purchased from nomadic Fulanis' who drive the herd, feed on plants beside main roads and elsewhere. However, the plants which cannot metabolize heavy metals are constantly exposed to the metals from car's exhaust fume and the metals could have been probably passed to the cattle while browsing on the plants. Thus, the undigested plant materials containing loads of heavy metals form the rumen waste, which is disposed off into the abattoir environs after cattle is slaughtered.

Soil has been described as a reservoir of pollutants, and mineralization of dead earthworms releases accumulated heavy metals back to the soil (Morgan \& Morgan, 1988). These may explain the reason why the levels of all metals analyzed in the abattoir soil where found higher than the concentration of metals in the tissue of all the earthworm species obtained from the abattoir locations. Also, high concentrations of metals observed in the rumen waste from the abattoir may have influenced the presence of metals in their respective soil samples as the concentration of $\mathrm{Cu}, \mathrm{Zn}, \mathrm{Co}, \mathrm{Ni}, \mathrm{Cr}$ and $\mathrm{Mn}$ followed the trend rumen waste>abattoir soil $>$ earthworm tissue $>$ control site.

Indigenous earthworms such as Libyodrilus violaceus, Alma millsoni and Eudrilus eugeniae in this study were revealed to bio-accumulate heavy metals in their body tissues from their soil substrates as has been reported for various earthworm species by other workers. Swati and Vikram (2011) had earlier reported higher concentration of $\mathrm{Pb}, \mathrm{Zn}$, $\mathrm{Mn}, \mathrm{Cu}$ and $\mathrm{Cd}$ in the tissue of $E$. eugeniae and Eisenia fetida used for vermicomposting urban waste. This, according to Edwards and Bohlen (1996), was due to the chemical and microbial changes that ingested substrates undergo during their passage through the alimentary canal of the earthworm. It was pointed out that 
a great proportion of the organic fraction is converted into soluble forms that are more available to organisms. These also include the heavy metal fractions chelated by these organic fractions, hence, their accumulation in the tissues of the earthworms.

Furthermore, as noted above, though all the earthworm species collected from the abattoir vicinity bio-accumulate heavy metals, $L$. violaceus was observed to bio-accumulate higher concentrations of heavy metals when compared to Eudrilus eugeniae, and this may be attributed to individual differences in their habits. While L. violaceus is a limicolous (marsh dwelling) species that rarely migrates from its habitat, E. eugeniae by nature is gregarious and this may have prevented bioaccumulation of these heavy metals to such higher concentrations as observed in L. violaceus. This observation agreed with the study of Hobbelen et al. (2006) which showed that the accumulation behavior of heavy metals in earthworms and their sensitivity to these pollutants, vary from species to species.

The concentrations of heavy metals in earthworm tissues were found to be directly dependent on their concentrations in the respective abattoir soils. The earthworms E. eugeniae and $L$. violaceus collected from all three abattoirs in this study, also recorded significantly higher concentrations of heavy metals than Alma millsoni from the Arboretum (control site). This signified that the abattoir soils in this study contained higher levels of heavy metals than the control site soil. This agreed with the work of Gupta, Tewari, Srivastava, Murthy, and Chandra (2005), who reported that earthworm tissue metal level is directly related to their proportion in a given soil. Similar pattern of metal bioaccumulation was observed by Suthar, Singh, and Dhawan (2008). Their finding that tissue-metal level reflects the metal availability in the soil further explain the reason why the average metal concentrations of $\mathrm{Cu}, \mathrm{Zn}, \mathrm{Pb}, \mathrm{Cd}, \mathrm{Ni}$ and $\mathrm{Mn}$ were highest in the tissue of earthworm species collected from Lafenwa abattoir, where the concentration of these metals were also found to be higher in its soil samples. The higher concentrations of these heavy metals in Lafenwa abattoir soil samples may be attributed to its old age and the observed larger volume of slaughtering activities which resulted in higher organic matter and carbon load in its soil.

The observed increase in the GST activities in the earthworm tissues from the sampling sites could be a protective measure against heavy metals toxicity. According to Lukkari, Taavitsainen, Vaisanen, and Haimi (2009), the role of GST is to detoxify electrophile intermediate compounds by conjugation with glutathione and several xenobiotics and heavy metals induced increased activity of the GST system in exposed organisms. The significant increased GST activity observed in this work may be related to free radical reactions, resulting in the induction of metal-binding protein and the subsequent metal sequestering, to result in its presence in a biologically inactive form, thus enabling the survival of the organism (Radwan, El-Gendy, \& Gad, 2010). The observed increase in GST activity in this study agreed with the work of Saint-Denis, Narbonne, Arnaud, Thybaud, and Ribera (1999), who observed increase in GST activity in earthworms exposed to benzo(a)pyrene after three weeks of exposure.

There were significant positive correlations between GST activities and the metal concentrations in all the earthworm species, from all study sites. These findings agreed with the work of Lukkari et al. (2004) who observed a significant correlation between GST activities and metal concentrations in Apporectodea tuberculata, exposed to $\mathrm{Zn}$ and $\mathrm{Cu}$, and concluded that GST appears to represent an efficient biomarker in monitoring soil contamination with these metals. Saint-Denis et al. (2001) also observed similar effect after Eisenia fetida exposure to $\mathrm{Pb}$.

This study revealed that earthworms accumulated some amount of heavy metals from abattoir soils, thus, can be used as a pollution bio-indicator for heavy metals. The heavy metal accumulated by earthworms is correlated to the metal concentrations in the soil and some 
soil physico-chemical parameters such as soil $\mathrm{pH}$ and organic matter. This study also suggested that Libyodrilus violaceous could be a suitable bio-indicator for pollution. In addition, the availability in the abattoir soils was influenced by the soil $\mathrm{pH}$, the soil organic matter, rumen waste and the age of the abattoir, accounting for the variations in metal concentration from one abattoir site to the other. The high GST activities observed in earthworm species obtained from the abattoir sites make it potentially useful biomarker to monitor heavy metal contaminations. This study also revealed that possible contamination by metals is possible as a result of indiscriminate disposition of abattoir waste into environments. It is therefore recommended that indiscriminate disposition of abattoir waste be discouraged to prevent possible transfer of toxic metals into the food chain.

\section{ACKNOWLEDGMENTS}

The authors appreciate the effort of Iyabode Olabisi Fluorence Dedeke for giving us expert advice during the design of this work.

\section{REFERENCES}

Adelegan, J. A. (2002). Environmental policy and slaughterhouse waste in Nigeria. $228^{\text {th }}$ WEDC Conference Report, Calcutta, India.

Agbaire, P. O. \& Emoyan, O. O. (2012). Bioaccumulation of heavy metals by earthworm (Lumbricus terrestris) and associated soils in domestic dumbsites in Abraka, Delta State, Nigeria. International Journal of Plant, Animal and Environmental Sciences, 2(3), 210-217.

A.O.A.C. (2000). Official methods of Analysis of A.O.A.C., International (17 ${ }^{\mathrm{TH}}$ Edition. Vol. II. 920-957). A.O.A.C., International: Gaithen burf, M.D, USA.

Asonye, C. C., Okolie, N. P., Okenwa, E. E., \& Iwuanyanwu, U. G. (2007). Some physico-chemical characteristics and heavy metal profiles of Nigerian rivers, streamsnd waterways. African Journal of Biotechnology, 6(5), 617-624.

Bezchlebova, J., Cernohlavkova, J., Ivana Sochova, J. L., Kobeticova, K., \& Hofman, J. (2007). Effects of toxaphene on soil organisms. Ecotoxicology and Environmental Safety, 68(3), 326-334.
Booth, L. H., Heppelthwaite, V., \& Mc Glinchy, A. (2000). The effect of environmental parameters on growth, cholinesterase activity and glutathione S-transferase activity in the earthworm Aporectodea caliginosa. Biomarkers, 5(1), 46-55.

Coker, A. O., Olugasa, B. O., \& Adeyemi, A. O. (2001). Abattoir waste water quality in South Western Nigeria, Proceedings of the 27th WEDC Conference: 329-331, Lusaka, Zambia, Loughborough University, United Kingdom.

Corp, N., \& Morgan, A. J. (1991). Accumulation of heavy metals from polluted soils by the earthworm, Lumbricus rubellus: Can laboratory exposure of 'control' worms reduce biomonitoring problems? Environmental Pollution, 74, 39-52.

Criel, P., Lock, K., Van Eeckhout, H., Oorts, K., Smolders, E., \& Janssen, C. R. (2008). Influence of soil properties on copper toxicity for two soil invertebrates. Environmental Toxicology and Chemistry, 27(8), 1748-1755.

Davey, B. G., \& Conyers, M. K. (1988). Determining the $\mathrm{pH}$ of acid soils. Soil Science, 146, 141-150.

Edwards, C. A., \& Bohlen, P. J. (1996). Biology and Ecology of Earthworms (third ed). London: Chapman and Hall.

Gupta, S. K., Tewari, A., Srivastava, R., Murthy, R. C., \& Chandra, S. (2005). Potential of Eisenia foetida for sustainable and efficient vermicomposting of fly ash. Water Air and Soil Pollution, 163, 293-302.

Habig, W. H., Pabst, M. J., \& Jakoby, W. B. (1974). Glutathione S- transferases. The first enzymatic step in mercapturic acid formation. Journal of Biological Chemistry, 249(22), 7130-7139.

Haimi, J., \& Mätäsniemi, L. (2002). Soil decomposer animal community in heavy-metal contaminated coniferous forest with and without liming. European Journal of Soil Biology, 38, 131-136.

Hobbelen, P. H. F., Koolhaas, J. E., \& Van Gestel, C. A. M. (2006). Bioaccumulation of heavymetals in the earthworms Lumbricus rubellus and Aporrectodea caliginosa in relation to total and available metal concentrations in field soils. Environmental Pollution, 144(2), 639-646.

Itodo, I. N., \& Awulu, J. O. (1991). Effects of Total Solids Concentration of poultry, cattle, and piggery waste. American Sociecity of Agricultural Engineers Journal, 3(2), 121-128

Lanno, R., Wells, J., Conder, J., Bradham, K., \& Basta, N. (2004). The biovailability of chemicals in soil for earthworms. Ecotoxicology and Environmental Safety, 57(1), 39-47. 
Lukkari, T., Taavitsainen, M., Väisänen, A., \& Haimi, J. (2009). Effects of heavy metals on earthworms along contamination gradients in organic rich soil. Ecotoxicology Environmental Safety, 59(3), 340-348.

Merrington, G., Winder, L., Parkinson, R. \& Redman, M. (1984). Agricultural Pollution: Environmental Problems and Practical Solutions. London: Taylor and Francis (Spon Press).

Miranda, M., Benedito, J. L., Blanco-Penedo, I., LópezLamas, C., Merino, A. \& López-Alonso, M. (2009). Metal accumulation in cattle raised in a serpentinesoil area: Relationship between metal concentrations in soil, forage and animal tissues. Journal of Trace Element in Medical Biology, 23, 231-238.

Morgan, J. E., \& Morgan, A. J. (1988). Earthworms as biomonitors of Cadmium, Lead and Zinc in metalliferous soils. Environmental Pollution, 54, 123-138.

Nelson, W., \& Bommers, L. E. (1982). Total Carbon, Organic Carbon and Organic Matter. In A. L. Page (Ed.), Methods of Soil Analysis Part, Chemical and Microbiological Properties. Wisconsin, U.S.A.: American Society of Agronomy.

Owa, S. O. (1992). Taxonomy and distribution of Nigerian earthworms of family Eudrilidae and their use as possible indicators of soil properties (Ph.D thesis). Obafemi Awolowo University, Ile-Ife, Nigeria.

Qaszczyca, P., Augustyniak, M., Babczynska, A., Bednarska, K., Kafel, A., Migula, P., Wilczek, G., \& Witas, I. (2004). Profiles of enzymatic activity in earthworms from zinc, lead and cadmium polluted areas near Olkusz (Poland). Environment International, 30, 901-910.

Radwan, M. A., El-Gendy, K. S., \& Gad, A. F. (2010). Biomarkers of oxidative stress in the land snail, Theba pisana for assessing ecotoxicological effects of urban metal pollution. Chemosphere, 79, 40-46.

Rao, J. V., Pavan, Y. S., \& Madhavendra, S. S. (2003). Toxic effects of chlorpyrifos on morphology and acetylcholinesterase activity in the earthworm, Eisenia foetida. Ecotoxicology and Environmental Safety, 54(3), 296-301.

Saint-Denis, M., Narbonne, J. F., Arnaud, C., Thybaud, E., \& Ribera, D. (1999). Biochemical responses of the earthworm Eisenia fetida andrei exposed to contaminated artificial soil: effects of benzo(a) pyrene. Soil Biology \& Biochemistry, 31, 1837-1846.

Saint-Denis, M., Narbonne, J. F., Arnaud, C., \& Ribera, D. (2001). Biochemical responses of the earthworm Eisenia fetida exposed to contaminated artificial soil, effects of lead acetate. Soil Biology \& Biochemistry, 33(3), 395-404.

Salehi, A., \& Tabari, M. (2008). Accumulation of $\mathrm{Zn}, \mathrm{Cu}$, $\mathrm{Ni}$ and $\mathrm{Pb}$ in soil and leaf of Pinus elderica Medw. Following irrigation with municipal effluent. Resource Journal of Environmental Science, 2(4), 291-297.

Sharma, R. P, Sharma, J. P., \& Megh, S. (2003). Correlation studies of Micronutreients vis-à-vis soil properties in some soils of Nagaur District in Semi-arid region of Rajasthan. Journal of Indian Society of Science, 51(4), 522-527.

Suthar, S., Singh, S., \& Dhawan, S. (2008). Earthworm as bioindicators of metals $(\mathrm{Zn}, \mathrm{Fe}, \mathrm{Mn}, \mathrm{Cu}, \mathrm{Pb}$ and Cd) in soils: Is metal bioaccumulation affected by their ecological categories. Ecological Engineering, 32, 99-107.

Svendsen, C., Spurgeon, D. J., Hankard, P. K., \& Weeks, J. M. (2004). A review of lysosomal membrane stability measured by neutral red retention: is it a workable earthworm biomarker? Ecotoxicology \& Environmental Safety, 57(1), 20-29.

Swati, P. \& Vikram, M. R. (2011). Heavy metals remediation from urban wastes using three species of earthworm (Eudrilus eugeniae, Eisenia fetida \& Perionyx excavates). Journal of Environmental Chemistry and Ecotoxicology, 3(14), 345-356.

United State Department of Agriculture (USDA). (2000). Heavy Metal Soil Contamination. Soil Quality-Urban Technical note No. 3. Natural Resources Conservation Service. Soil Quality Institute, Donahue Dr. Auburn, AL, USA.

Walker, C. H. (1998). Biomarker strategies to evaluate the environmental effects of chemicals. Environmental Health Pespectives, 106(2), 613-520.

Ward, N. I., \& Savage, J. M. (1994). Elemental status of grazing animals located adjacent to the London Orbital (M25) motorway. Science Total \& Environment, 147, 185-189. 
